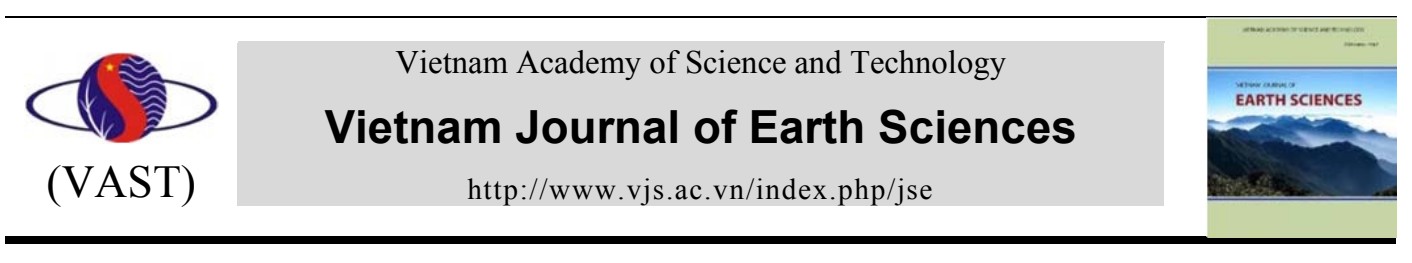

\title{
Assessment of heavy metal pollution in abandoned Giap Lai pyrite mine (Phu Tho Province)
}

\author{
Pham Tich Xuan*, Nguyen Thi Lien, Pham Thanh Dang, Doan Thi Thu Tra, Nguyen Van Pho, \\ Nguyen Xuan Qua, Hoang Thi Tuyet Nga
}

Institute of Geological Sciences (VAST)

Received 30 March 2017. Accepted 31 May 2017

\begin{abstract}
Giap Lai pyrite mine had been exploited in the period 1975 - 1999, and abandoned after the mine became closed. This work is conducted with the aim to evaluate the impacts of the abandoned mine to the environment. 23 surface water, 15 ground water and 20 soil samples from the mining area were collected for experiments. Acid production potential and metal leaching of waste materials from tailings were tested. Results show that acid rock drainage (ARD) in the old mining area still occurs, with sulfide-rich tailings and waste rocks being sources of ARD, causing elevated metal concentrations in downstream water bodies. Surface water shows significant pollution of Fe, Mn, Ni and partially As. In the rainy season, the percentage of surface water samples having low $\mathrm{pH}$ values as well as metal contents in samples is higher than in the dry season. Metal concentrations in ground water are generally low, but many samples have low $\mathrm{pH}$ values, indicating the influence of the ARD. The geo-accumulation index reveals that soil from mining area is moderately contaminated with $\mathrm{Ni}, \mathrm{Cu}, \mathrm{Hg}$ and partially As. Most of the polluted samples are located near old mining pits, waste dumps and tailing ponds. The study also shows that negative effect of Giap Lai pyrite mine on the surrounding water and soil has been ongoing. However, no post-closure remediation measures have been applied at the mine, so there must be appropriate solutions for the acid mine drainage treatment before its being discharged to the environment. Given the facts revealed by this study, it is recommended that the Environmental Protection Law should be fully implemented at mining sites not only during the exploitation but also after their closures.
\end{abstract}

Keywords: pyrite mine, abandoned mine, acid drainage, metal pollution.

(C)2017 Vietnam Academy of Science and Technology

\section{Introduction}

Mining and mineral processing can cause many negative impacts on the environment. The formation of acid mine drainage (AMD) and acid rock drainage (ARD) and associated contamination has been described as the largest environmental problem in sulfide- bearing

"Corresponding author, Email: xuanpt@igsvn.ac.vn mines (INAP, 2009). The generation of acid is due to oxidation of sulfide minerals existing in ore, especially pyrite $\left(\mathrm{FeS}_{2}\right)$, when they exposed to air and water. Already formed acid is able to dissolve metals and these contaminants, once dissolved, can migrate to local surface water causing environmental pollution. These processes occur during the operation of a mine and can continue for a long 
Pham Tich Xuan, et al./Vietnam Journal of Earth Sciences 39 (2017)

time, even hundreds of years after the mine closing (Ziemkiewicz et al., 1991). Due to the impact of acid mine drainage and heavy metal pollution, water quality, especially mine land usually was seriously degraded, even impossible to recover and most of the land so often become fallow.

Up to now, in the world literature, there are a huge number of publications on abandoned mines. Many countries have special agencies or programs for research of closed mines (EPA, 2000; MCMPR/MCA, 2010; Mhlongo and Amponsah-Dacosta, 2015; Newton et al., 2000).

In Viet Nam, studies of the post-mining environment are limited. Recently, there is only one report by Tarras-Wahlberg and Lan (2008) on the post-mining environment at Giap Lai pyrite mine. According to these authors, at Giap Lai pyrite mine the ARD is still leaking and metal concentrations in affected surface waters have been increased since the mine closure, suggesting that the impact is becoming progressively serious. The authors also suggest that the present situation is due to the failure in post-mining management.

Mining of pyrite in Giap Lai occurred during the period 1975-1999 and had been closed since 1999. Currently, the old mining pits have turned into acid lakes, and acid drainage continues to form from waste rock dumps and tailings ponds, causing pollution of some heavy metals (Tarras-Wahlberg and Lan, 2008).

Environmental pollution in the Giap Lai mining area has caused anxiety among the people and led to numerous complaints. Pollution is believed to be the main cause in rising fatal diseases in the commune in the recent years.

This paper presents new findings of acid rock drainage phenomenon and heavy metals pollution in the abandoned Giap Lai pyrite mine area to provide the scientific basis for the management of the closed mines and mining environmental protection in general.

\section{Study area}

Giap Lai pyrite mine locates in Giap Lai commune, Thanh Son District, Phu Tho Province, about $80 \mathrm{~km}$ northwest from Ha Noi (Figure 1). The area is a valley-shaped running in the northwest - southeast direction at an altitude of about $70 \mathrm{~m}$, among low hills, which reach $200-400 \mathrm{~m}$ high. The mining area is drained by Dong Dao stream, which empties into the Bua River about $6.5 \mathrm{~km}$ to the northwest.

Like all of North Vietnam, Giap Lai is located in the tropical monsoon climate. There are two distinct seasons: The rainy season coincides with the hot season starting from April to the end of September, the average temperature is from $27^{\circ} \mathrm{C}$ to $31^{\circ} \mathrm{C}$ and the highest is $30^{\circ} \mathrm{C}-39^{\circ} \mathrm{C}$; The dry season starts from October to the end of March next year, the average temperature is $20^{\circ} \mathrm{C}-22^{\circ} \mathrm{C}$ and the lowest is $6^{\circ} \mathrm{C}-15^{\circ} \mathrm{C}$. Annual rainfall is about $2500 \mathrm{~mm}$, mainly concentrated in the rainy season, especially June, July and August.

The vein type massive ore bodies were distributed in metamorphic rocks of the Thach Khoan formation (NP $-\epsilon_{1} t k$ ) consisting of two mica - garnet - quartz schist, mica - staurolite - disten schist, quartzite and marble.

The ore mineral compositions comprised mainly of pyrite $\left(\mathrm{FeS}_{2}\right)$ with minor pyrrhotite $(\mathrm{Fe}(1-\mathrm{x}) \mathrm{S})$ and a very small amount of other sulfide minerals such as chalcopyrite $\left(\mathrm{CuFeS}_{2}\right)$, galena $(\mathrm{PbS})$, sphalerite $(\mathrm{ZnS})$. The sulfur content (S) of ore ranges from 15 to $30 \%$ and average about $24.45 \%$ (Tran Xuan Toan, 1963).

Mining of pyrite in Giap Lai mine occurred during the period 1975 - 1999, after which these operations ceased. The pyrite mine included 3 open pits which recently became 3 lakes (hereafter referred as lake No.1, No.2 and No.3) (Figure 2 and 3). During pyrite mining, a total of over 5 millions $\mathrm{m}^{3}$ of overburden was removed. Approximately, 1 million $\mathrm{m}^{3}$ of waste rocks were put into the waste dump, which located northeast of min- 
ing pits, and a significant portion of rest waste rocks was used to backfill mining pits themselves. There are also 2 tailings deposits located in the north of mine (Figure 3 ). The first tailing dam was active until the late
1980 s and contains approximately 200,000 tons of tailings. The second dam operated from the late 1980s until mining ended and contains approximately 880,000 tons of tailings (Tarras-Wahlberg and Lan, 2008).

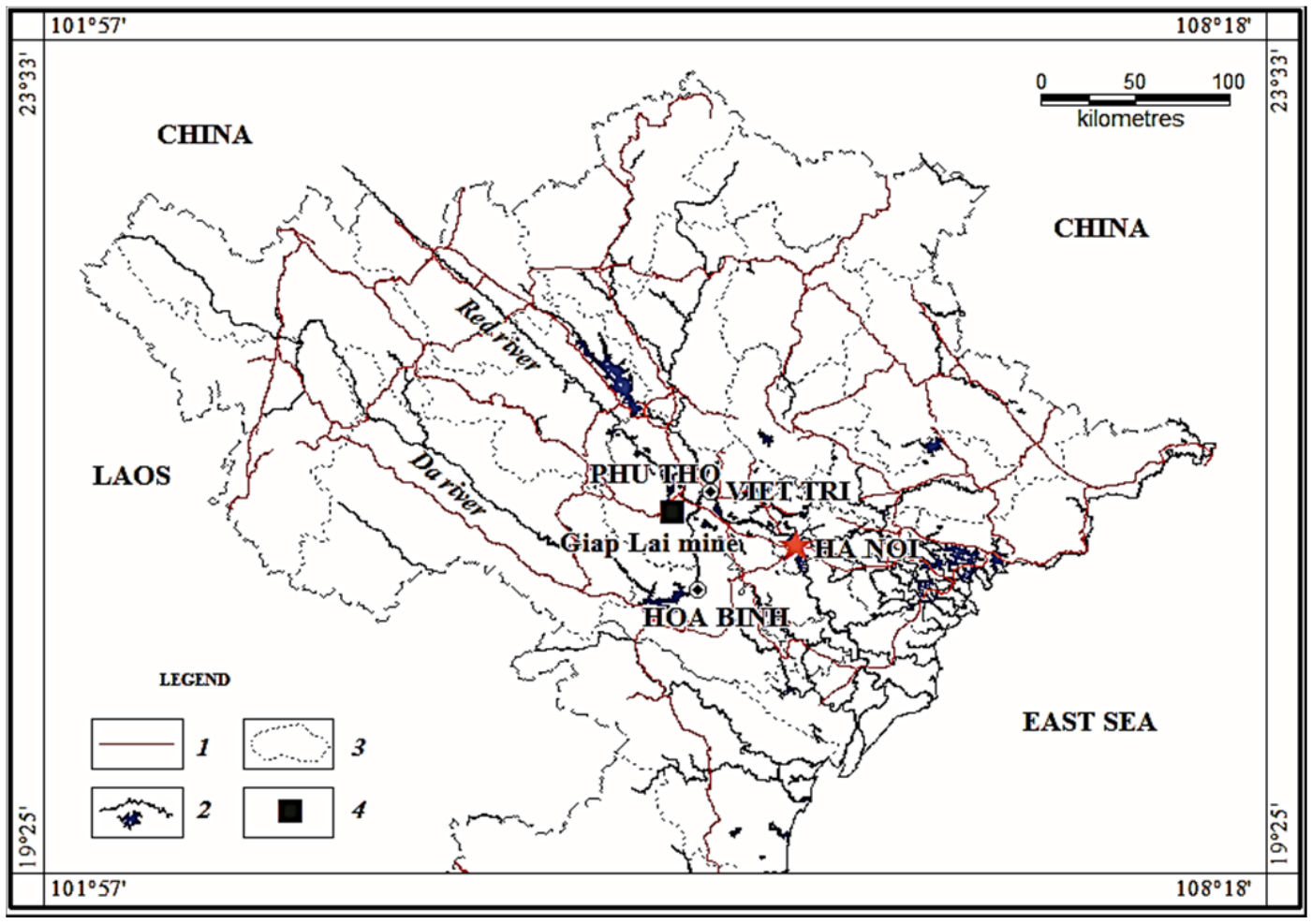

Figure 1. Map showing location of Giap Lai mine in Northern Vietnam 1- Roads, 2- Rivers and Lakes, 3- Provincial boundaries, 4- Giap Lai mine
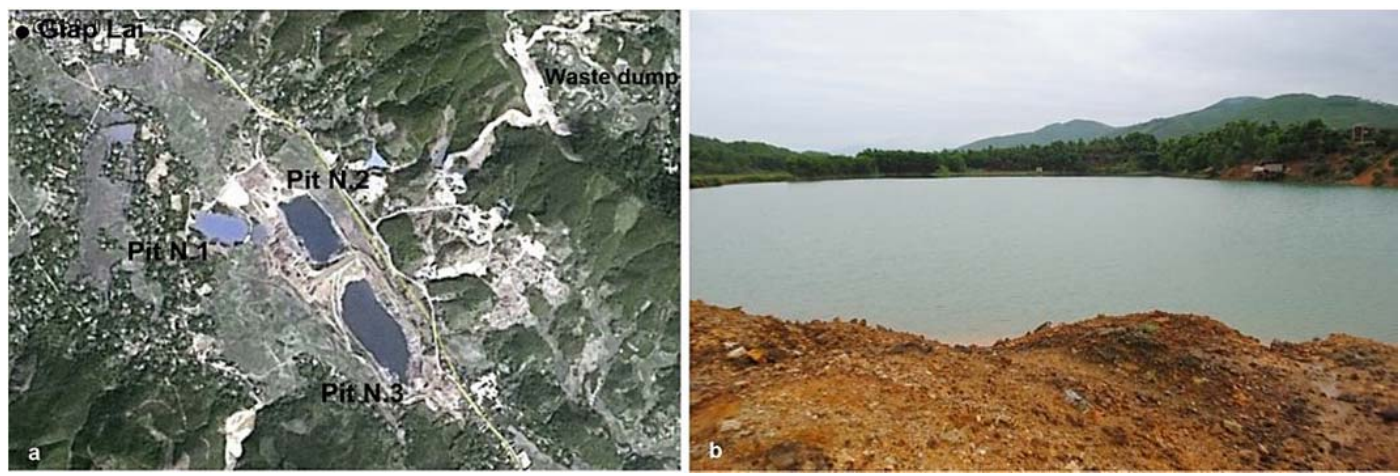

Figure 2. a) Three lakes are formed from old mining pits; b) view of Lake N.2 (open pit N.2) 


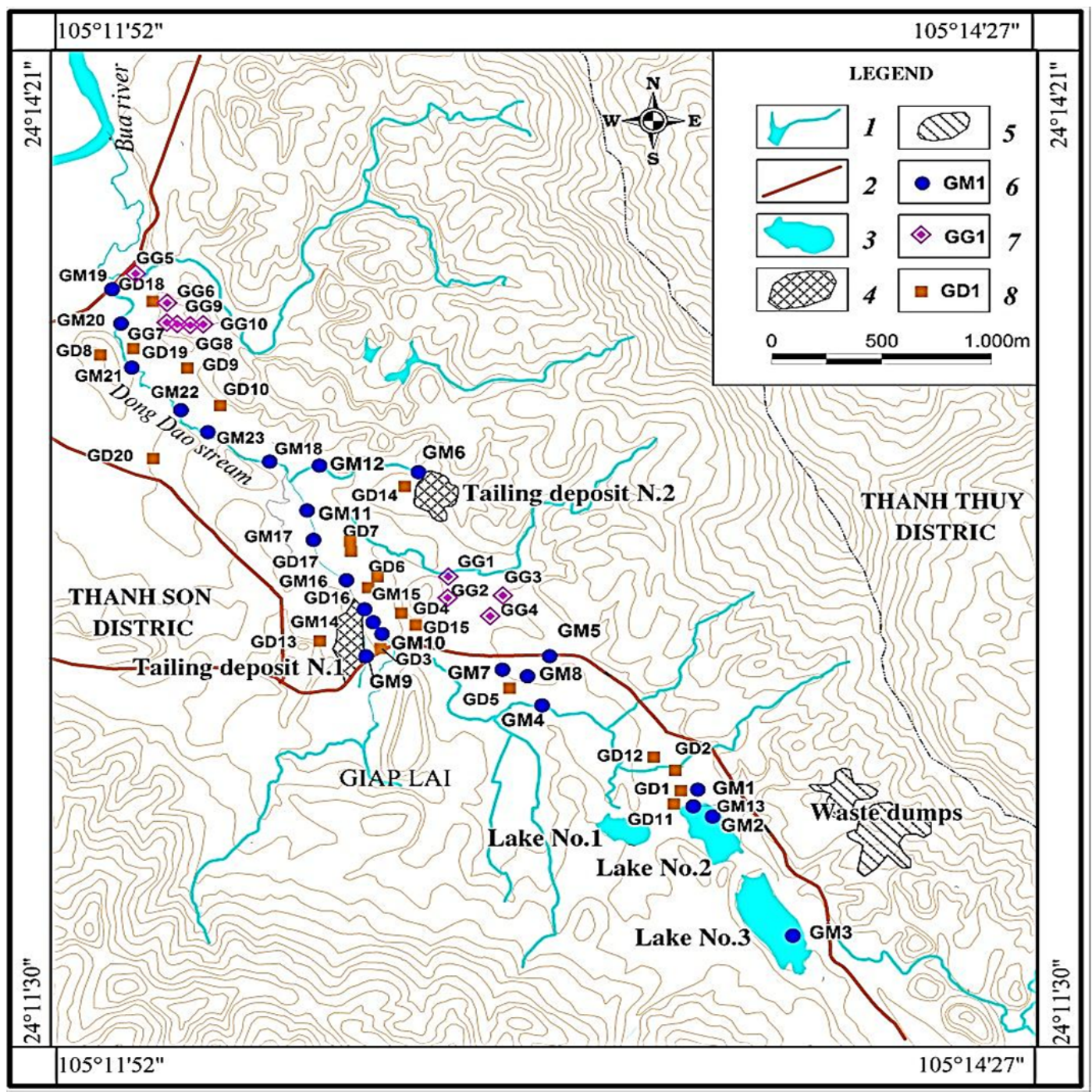

Figure 3. Map of sampling sites at Giap Lai mining area

1- Water bodies, 2. Road, 3- Lakes (old pits), 4 - Tailing deposit, 5 - Waste dumps, 6 - Surface water sampling point,

7 - Ground water sampling point, 8 - Soil sampling points

\section{Material and methods}

The sample collection included 23 surface water samples (12 samples were taken during the rainy season and 11 others during the dry season), 15 samples of well water and 20 soil samples. Locations of sampling points are shown in Figure 3.
Each water sample was taken into $02 \mathrm{PE}$ bottles of $0.5 \mathrm{~L}$ capacity and was treated with the ultrapure $\mathrm{HNO}_{3}$ solution to prevent precipitation. The water samples were filtered through a $0,45 \mu \mathrm{m}$ filter paper.

The soil samples were taken in an amount of $1-2 \mathrm{~kg}$ from the surface layer $(15-20 \mathrm{~cm})$ and stored in PE plastic bags. In the laborato- 
ry, samples were air-dried at room temperature. They were pulverized, then passed through $1 \mathrm{~mm}$ sieve to remove grit and plant residues. The fine fraction was well mixed, and about $100 \mathrm{~g}$ was removed using the quartered method, then was finally ground with an agate mortar.

The $\mathrm{pH}$ is measured by handheld $\mathrm{pH}$ meter HANA HI8424 with precision $\mathrm{pH}= \pm 0.01$. Concentrations of $\mathrm{Fe}, \mathrm{Mn}, \mathrm{Ni}, \mathrm{Cu}, \mathrm{Zn}, \mathrm{Cd}, \mathrm{Pb}$ were analyzed by ICP-MS at the Institute of Geological Sciences, VAST, and concentrations of As, Se and $\mathrm{Hg}$ were analyzed by the same method using Vapor Generation Accessory (VGA-77).

Concentrations of $\mathrm{Cu}, \mathrm{Ni}, \mathrm{Co}$ in the leachates collected from experiments were analyzed by HACH DR2800 Spectrophotometer. The analytical precision for $\mathrm{Co}, \mathrm{Cu}$ is $\pm 0.01 \mathrm{mg} / \mathrm{L}$, and for $\mathrm{Ni}$ is $\pm 0.001 \mathrm{mg} / \mathrm{L}$.

Experiments were carried out to evaluate the acid production potential and metal leaching of waste materials from tailings deposit No.1:

- Experiment No.1 was field test using paste-pH method (Sobek et al., 1978). The procedure is as follows:

The paste-pH test was performed in December 2015 (dry season). The samples for paste-pH test were taken in waste dump No.1 in a $1.5 \mathrm{~m}$ deep profile. At each given depth in the profile a sample of $\sim 100 \mathrm{~g}$ (after removal of debris) was taken, and was mixed with deionized water at a ratio of 2:1 (solid: water), stirred, waited for about 30 minutes then measured for the $\mathrm{pH}$.

- Experiment No.2 is leaching test performed in the laboratory using the modified procedure of AMIRA "Free Draining Leach Column Test" (AMIRA, 2002). The waste rocks from tailings deposit No.1 were taken for leaching experiment. The samples after removing soil and weathered, loosen parts were dried and crushed to $1-2 \mathrm{~cm}$ pieces. About $2 \mathrm{~kg}$ of chipped rocks were used for the experiment. The analytical columns were PET 5-liter vessels having a tap at the bottom for water draining. The experiment procedure is described as follows:

Step 1 (wet step): fill the column with $1.5 \mathrm{~L}$ deionized water to submerge all of the test materials for $24 \mathrm{~h}$.

Step 2 (humid step): after $24 \mathrm{~h}$ drain off water from the columns and leave still for 7 days $(192 \mathrm{~h})$.

After 7 days, repeat steps 1 and 2, this experiment was repeatedly performed over a period of 54 days (1344 hours).

At each draining, the leachates were measured for $\mathrm{pH}, \mathrm{Eh}, \mathrm{Ec}$ and analyzed for concentrations of some heavy metals using DR2800.

The impact magnitude is evaluated based on the comparison with the reference standards from Vietnam National Technical Regulations including QCVN03-MT 2015/BTNMT (on soil), QCVN08-MT 2015/BTNMT (on surface water), QCVN09-MT 2015/BTNMT (on ground water), QCVN01:2009/BYT (on drinking water) and QCVN02:2009/BYT (on domestic water).

Metal contamination of soil is also evaluated by Geoaccumulation index $\left(\mathrm{I}_{\mathrm{geo}}\right)$. Geoaccumulation index $\left(\mathrm{I}_{\mathrm{geo}}\right)$ was originally introduced by Müller (1969) and has been widely used since to assess contamination levels of heavy metals in sediments (Muler, 1969, Çevik et al., 2009, Ghrefat et al., 2011, Nowrouzi and Pourkhabbaz, 2015). The geoaccumulation index is also used to assess the contamination of soil (Loska et al., 2003; Wei et al., 2011; Zawadzki and Fabijan'czyk, 2013).

Geoaccumulation index $I_{\text {geo }}$ is calculated using the below formula (after Muler, 1969; Loska et al., 2004):

$$
\mathrm{I}_{\text {geo }}=\log _{2}\left(\mathrm{C}_{\mathrm{n}} / 1,5 \times \mathrm{B}_{\mathrm{n}}\right)
$$

with $\mathrm{C}_{\mathrm{n}}$ is the measured concentration of examined element $n$ in the soil sample, $B_{n}$ - reference value of the elements $n$ and the factor 1.5 is used because of possible variations of the background data due to lithological variations. The quantity $I_{\text {geo }}$ is calculated using the reference data of trace elements in soil from IAEA-soil-7 (IAEA, 2000). 
Pham Tich Xuan, et al./Vietnam Journal of Earth Sciences 39 (2017)

Muller (1969) determined 7 classes from 0 to 6 according to $I_{\text {geo }}$ values and 7 corresponding contamination levels, which are given in Table 1.

Table 1. Contamination categories based on geoaccumulation index $\left(\mathrm{I}_{\text {geo }}\right)$ (Muller, 1969)

\begin{tabular}{|c|c|c|}
\hline Class & Value & Classification \\
\hline 0 & $<<0$ & Uncontaminated \\
\hline 1 & $0-1$ & $\begin{array}{l}\text { Uncontaminated to moderately contami- } \\
\text { nated }\end{array}$ \\
\hline 2 & $1-2$ & Moderately contaminated \\
\hline 3 & $2-3$ & Moderately to strongly contaminated \\
\hline 4 & $3-4$ & Strongly contaminated \\
\hline 5 & $4-5$ & $\begin{array}{l}\text { Strongly to extremely strongly contami- } \\
\text { nated }\end{array}$ \\
\hline 6 & $5-6$ & Extremely contaminated \\
\hline
\end{tabular}

\section{Results}

\section{1. pH measurements}

Table 2 presents the $\mathrm{pH}$ values in Pit (Lake) No.2 measured during the period 1995 - 2015. In 1997, when the mine was operational, thanked the applied control measures $\mathrm{pH}$ value of the water was normally high $\mathrm{pH}=$ 6.7. However, 3 years after mine closure, in 2002 the $\mathrm{pH}$ dropped to 3.1 (Table 2). Variation of $\mathrm{pH}$ values with time is shown in Figure 4. Surface water has $\mathrm{pH}$ ranged from 3.63 to 7.42 , and 7 out of 23 samples have $\mathrm{pH}$ lower than the limit for irrigation water (QCVN08MT 2015/BTNMT) and all of them are collected in the rainy season (Table 5). Water samples from wells have $\mathrm{pH}$ varying from 5.16 to 6.63 and generally meet the standard values for ground water (5.5 to 9 of QCVN09-
MT 2015/BTNMT), except for sample G15 having $\mathrm{pH}=5.16$, lower than the standard (Table 6).

Table 2. $\mathrm{pH}$ value of water in lake N.2 (old pit N.2) in time

\begin{tabular}{|c|c|c|c|c|}
\hline & Time & Site & $\mathrm{pH}$ & Source \\
\hline 1 & 9/1997 & Lake N. 2 & 6.7 & 1 \\
\hline 2 & $5 / 2002$ & Lake N. 2 & 3.1 & 1 \\
\hline 3 & $1 / 2011$ & Lake N. 2 & 5.2 & 2 \\
\hline 4 & $3 / 2011$ & Lake N. 2 & 5.16 & 2 \\
\hline 5 & $9 / 2011$ & Lake N. 2 & 4.8 & 2 \\
\hline 6 & $6 / 2013$ & Lake N. 2 & 5.49 & 2 \\
\hline 7 & $10 / 2015$ & Lake N. 2 & 5.35 & 2 \\
\hline
\end{tabular}

Source: 1 - Håkan Tarras-Wahlberg, Lan T. Nguyen (2008); 2 - This study

\subsection{Results of experiments}

The paste-pH tests show low $\mathrm{pH}$ values at all depths of the profile (ranged from 3.66 to 3.88 ), indicating that the pore water is acidic (Table 3, Figure 5). The leachates in leaching experiments have low $\mathrm{pH}$ values $(<2)$, while the concentrations of metals are very high. For example, concentrations of $\mathrm{Cu}, \mathrm{Ni}$ and $\mathrm{Co}$ vary from 60 to $570 \mathrm{mg} / \mathrm{L}, 1.1$ to $46.2 \mathrm{mg} / 1$ and 0.9 to $64.4 \mathrm{mg} / 1$ respectively. With time, $\mathrm{pH}$ values tend to increase, while the concentrations of metals decrease (Table 4, Figure 6).

Table 3. Results of paste-pH test in tailing N1

\begin{tabular}{|c|c|c|c|c|c|}
\hline Sampes & Depth $(\mathrm{cm})$ & $\mathrm{pH}$ & Sampes & Depth (cm) & $\mathrm{pH}$ \\
\hline P-1 & $0-10$ & 3.88 & P-6 & $75-90$ & 3.79 \\
\hline P-2 & $10-25$ & 3.68 & P-7 & $90-105$ & 3.76 \\
\hline P-3 & $25-40$ & 3.68 & P-8 & $105-120$ & 3.74 \\
\hline P-4 & $40-60$ & 3.66 & P-9 & $120-135$ & 3.76 \\
\hline P-5 & $60-75$ & 3.71 & P-10 & $135-150$ & 3.73 \\
\hline
\end{tabular}

Table 4. $\mathrm{pH}$ and concentrations of some metals in leaching experiments

\begin{tabular}{|c|c|c|c|c|c|c|c|c|c|}
\hline \multirow{2}{*}{ N. } & \multirow{2}{*}{ Leachat } & \multirow{2}{*}{$\mathrm{pH}$} & \multirow{2}{*}{$\mathrm{T}\left({ }^{\circ} \mathrm{C}\right)$} & \multirow{2}{*}{$\mathrm{Eh}(\mathrm{mV})$} & \multirow{2}{*}{$\mathrm{EC}(\mathrm{mS} / \mathrm{cm})$} & \multicolumn{3}{|c|}{ Concentration $(\mathrm{mg} / \mathrm{l})$} & \multirow{2}{*}{ Time (h) } \\
\hline & & & & & & $\mathrm{Cu}$ & $\mathrm{Ni}$ & $\mathrm{Co}$ & \\
\hline 0 & 0 & 7 & & & & & & & 0 \\
\hline 1 & TN1-01 & 1.77 & 30.9 & 260.2 & 130.2 & 570 & 46.2 & 59 & 24 \\
\hline 2 & TN1-02 & 1.72 & 30.5 & 266.7 & 123.9 & 232 & 20.6 & 64.4 & 192 \\
\hline 3 & TN1-03 & 1.77 & 30.8 & 268.2 & 90.3 & 104 & 4.8 & 14 & 384 \\
\hline 4 & TN1-04 & 1.86 & 28.4 & 254.3 & 67.1 & 78 & 2.8 & 7.4 & 576 \\
\hline 5 & TN1-05 & 1.82 & 29.8 & 258.4 & 62.5 & 70 & 2.2 & 4 & 960 \\
\hline 6 & TN1-06 & 1.85 & 30.7 & 264.5 & 56.6 & 64 & 1.5 & 2.8 & 1152 \\
\hline 7 & TN1-07 & 1.90 & 30.7 & 263.6 & 31.1 & 60 & 1.1 & 0.9 & 1344 \\
\hline
\end{tabular}

Concentration of $\mathrm{Fe}, \mathrm{Cu}, \mathrm{Ni}$, Co were analised by DR2800 spectrophotometry in Department of Geochemistry, IGS VAST 
Vietnam Journal of Earth Sciences, 39(3), 210-224

\subsection{Heavy metal concentrations}

Metal concentrations in the surface water vary in wide ranges (Table 5). Samples collected downstream of the lakes and the tailing impoundments shows high in $\mathrm{Fe}, \mathrm{Mn}, \mathrm{Ni}, \mathrm{Cu}$ and $\mathrm{As}$, but generally low in $\mathrm{Pb}, \mathrm{Cd}, \mathrm{Hg}$ and $\mathrm{Se}$ in all samples. In general, samples collected in the rainy season have higher metal concentrations as compared to samples collected in the dry season. Compared to the Standard (QCVN08-MT:2015/BTNMT, B1: irrigation water), in the rainy season, 10 out of 12 collected samples have Mn content exceeded the limit, but in the dry season, only one out of 11 analyzed samples have Mn content exceeded the limit. Similarly, for Fe, in the rainy season, 9 out of 12 samples have Fe content higher than allowed level, but in the dry season, only one out of 11 samples have Fe content higher than allowed level. Some samples collected in the rainy season contain high $\mathrm{Ni}$, while other samples, for example, sample M06 is contaminated by As (Table 5).

Heavy metal concentrations in the ground water are generally low, except for samples G3, G4 having high $\mathrm{Mn}(10.48 \mathrm{mg} / \mathrm{L}$ and $19.79 \mathrm{mg} / \mathrm{L}$ respectively) and $\mathrm{Ni}(0.065 \mathrm{mg} / \mathrm{L}$ and $0.52 \mathrm{mg} / \mathrm{L}$ respectively) and samples $\mathrm{G} 13$, G15 having high $\mathrm{Mn}$ contents $(2.59 \mathrm{mg} / \mathrm{L}$ and $3.69 \mathrm{mg} / \mathrm{L}$ respectively) as compared to the standard for ground water (QCVN09-MT 2015/BTNMT). The heavy metal concentrations in other samples are met the standard norms (Table 6).

Table 5. $\mathrm{pH}$ and concentrations of some metals in surface water from Giap Lai mining area $(\mathrm{mg} / \mathrm{l})$

\begin{tabular}{|c|c|c|c|c|c|c|c|c|c|c|}
\hline Samples & $\mathrm{pH}$ & $\mathrm{Mn}$ & $\mathrm{Fe}$ & $\mathrm{Ni}$ & $\mathrm{Cu}$ & $\mathrm{Zn}$ & As & $\mathrm{Cd}$ & $\mathrm{Hg}$ & $\mathrm{Pb}$ \\
\hline M1 & 5.2 & 1.98 & 0.23 & 0.0178 & 0.0037 & 0.0345 & 0.00032 & 0.00032 & 0.0002 & 0.00399 \\
\hline M2 & 4.08 & 26.27 & 10.43 & 0.6441 & 0.1114 & 0.4642 & 0.00171 & 0.00406 & 0.0003 & 0.02774 \\
\hline M3 & 5.49 & 0.43 & 2.03 & 0.0104 & 0.0062 & 0.0439 & 0.00603 & 0.00024 & 0.0003 & 0.03223 \\
\hline M4 & 4.14 & 31.05 & 25.15 & 0.4448 & 0.0898 & 1.1375 & 0.00023 & 0.00571 & 0.0003 & 0.01112 \\
\hline M5 & 5.95 & 4.74 & 4.29 & 0.0641 & 0.0183 & 0.1864 & 0.00053 & 0.00087 & 0.0003 & 0.00361 \\
\hline M6 & 3.63 & 1.56 & 477.05 & 0.2013 & 0.3978 & 0.2441 & 0.99428 & 0.00105 & 0.0003 & 0.00400 \\
\hline M7 & 5.03 & 8.49 & 41.20 & 0.1024 & 0.0653 & 0.1574 & 0.00687 & 0.00149 & 0.0015 & 0.0594 \\
\hline M8 & 6.6 & 0.14 & 0.62 & 0.0042 & 0.0055 & 0.0226 & 0.00127 & 0.00003 & 0.0019 & 0.00176 \\
\hline M9 & 6.5 & 4.71 & 7.66 & 0.0641 & 0.0183 & 0.1833 & 0.00048 & 0.00084 & 0.0003 & 0.00357 \\
\hline M10 & 6.57 & 3.98 & 2.03 & 0.0384 & 0.0099 & 0.1601 & 0.00064 & 0.00005 & 0.0002 & 0.00249 \\
\hline M11 & 6.71 & 2.96 & 1.48 & 0.0269 & 0.0010 & 0.1391 & 0.00071 & 0.00004 & 0.0002 & 0.00287 \\
\hline M12 & 6.72 & 1.78 & 0.92 & 0.0178 & 0.0011 & 0.1058 & 0.00075 & 0.00003 & 0.0010 & 0.00301 \\
\hline M13 & 5.16 & 0.007 & 0.13 & 0.0259 & 0.0052 & 0.1473 & 0.00435 & 0.00052 & 0.0144 & 0.01506 \\
\hline M14 & 6.06 & 38.05 & 48.15 & 0.4448 & 0.0898 & 1.1375 & 0.00073 & 0.00571 & 0.00029 & 0.01112 \\
\hline M15 & 7.38 & 0.006 & 0.33 & 0.0010 & 0.0119 & 0.0094 & 0.00307 & 0.00005 & 0.00198 & 0.0008 \\
\hline M16 & 7.42 & 0.004 & 0.31 & 0.0010 & 0.0028 & 0.0156 & 0.00217 & 0.00004 & 0.00073 & 0.00085 \\
\hline M17 & 7.42 & 0.004 & 0.29 & 0.0011 & 0.0023 & 0.0161 & 0.00226 & 0.00002 & 0.00043 & 0.00081 \\
\hline M18 & 7.38 & 0.003 & 0.26 & 0.0009 & 0.0030 & 0.0101 & 0.00220 & 0.00003 & 0.00029 & 0.00054 \\
\hline M19 & 7.24 & 0.006 & 0.17 & 0.0007 & 0.0032 & 0.0139 & 0.00212 & 0.00004 & 0.00022 & 0.00054 \\
\hline M20 & 7.32 & 0.003 & 0.17 & 0.0009 & 0.0020 & 0.0114 & 0.00200 & 0.00003 & 0.00016 & 0.00032 \\
\hline M21 & 7.32 & 0.002 & 0.15 & 0.0008 & 0.0021 & 0.0107 & 0.00204 & 0.00003 & 0.00014 & 0.00030 \\
\hline M22 & 7.28 & 0.003 & 0.18 & 0.0008 & 0.0023 & 0.0084 & 0.00227 & 0.00002 & 0.00013 & 0.00044 \\
\hline M23 & 7.29 & 0.002 & 0.16 & 0.0007 & 0.0022 & 0.0098 & 0.00229 & 0.00003 & 0.00012 & 0.00034 \\
\hline Bua River & 7.40 & & & 0.0004 & 0.0007 & 0.001 & 0.00024 & 0.00001 & - & 0.00012 \\
\hline STD & $5.5-9$ & 0.50 & 1.50 & 0.100 & 0.500 & 1.500 & 0.05 & 0.01000 & 0.0010 & 0.05 \\
\hline
\end{tabular}

Note: M1 - M12: collected in the rainy season; M13 - M23: collected in the dry season. All samples were analyzed by ICP-MS in IGS - VAST. STD: Vietnam National Technical Regulations on surface water (QCVN08MT:2015/BTNMT - B1: irrigation water) 
Pham Tich Xuan, et al./Vietnam Journal of Earth Sciences 39 (2017)

Table 6. $\mathrm{pH}$ and concentrations of some metals in well water from Giap Lai mining area (mg/l)

\begin{tabular}{|c|c|c|c|c|c|c|c|c|c|c|c|}
\hline Samples & $\mathrm{pH}$ & $\mathrm{Mn}$ & $\mathrm{Fe}$ & $\mathrm{Ni}$ & $\mathrm{Cu}$ & $\mathrm{Zn}$ & As & $\mathrm{Se}$ & $\mathrm{Cd}$ & $\mathrm{Hg}$ & $\mathrm{Pb}$ \\
\hline G1 & 6.63 & 0.01 & 0.37 & 0.0080 & 0.0014 & 0.0156 & 0.0007 & 0.0007 & 0.0001 & 0.0017 & 0.0012 \\
\hline $\mathrm{G} 2$ & 6.53 & 0.15 & 0.36 & 0.0057 & 0.0031 & 0.0336 & 0.0012 & 0.0012 & 0.0001 & 0.0010 & 0.0010 \\
\hline G3 & 5.78 & 10.48 & 0.64 & 0.0646 & 0.0149 & 0.2159 & 0.0014 & 0.0009 & 0.0021 & 0.0008 & 0.0043 \\
\hline G4 & 5.83 & 19.79 & 1.45 & 0.5149 & 0.0348 & 0.3456 & 0.0007 & 0.0044 & 0.0048 & 0.0006 & 0.0018 \\
\hline G5 & 6.29 & 0.09 & 0.14 & 0.0039 & 0.0018 & 0.0242 & 0.0000 & 0.0002 & 0.0001 & 0.0009 & 0.0004 \\
\hline G6 & 5.8 & 0.64 & 0.10 & 0.0120 & 0.0016 & 0.0203 & 0.0006 & 0.0002 & 0.0003 & 0.0009 & 0.0009 \\
\hline G7 & 5.57 & 0.04 & 0.14 & 0.0029 & 0.1545 & 0.0268 & 0.0005 & 0.0017 & 0.0001 & 0.0007 & 0.0051 \\
\hline G8 & 5.9 & 0.21 & 0.11 & 0.0062 & 0.0014 & 0.1784 & 0.0001 & 0.0005 & 0.0002 & 0.0008 & 0.0004 \\
\hline G9 & 5.88 & 0.02 & 0.22 & 0.0013 & 0.0021 & 0.0217 & 0.0000 & 0.0012 & 0.0001 & 0.0004 & 0.0005 \\
\hline G10 & 5.66 & 0.09 & 0.07 & 0.0128 & 0.0039 & 0.0750 & 0.0025 & 0.0000 & 0.0001 & 0.0006 & 0.0005 \\
\hline G11 & 5.75 & 0.01 & 0.05 & 0.0010 & 0.0010 & 0.0228 & 0.0005 & 0.0003 & 0.0001 & 0.0004 & 0.0003 \\
\hline G12 & 6.56 & 0.00 & 0.12 & 0.0029 & 0.0014 & 0.0141 & 0.0002 & 0.0001 & 0.0000 & 0.0004 & 0.0005 \\
\hline G13 & 5.65 & 2.59 & 0.09 & 0.0173 & 0.0041 & 0.7456 & 0.0003 & 0.0006 & 0.0009 & 0.0005 & 0.0010 \\
\hline G14 & 6.2 & 0.96 & 0.52 & 0.0094 & 0.0029 & 0.0358 & 0.0069 & 0.0027 & 0.0004 & 0.0003 & 0.0003 \\
\hline G15 & 5.16 & 3.69 & 0.40 & 0.0321 & 0.0064 & 0.1002 & 0.0018 & 0.0059 & 0.0006 & 0.0003 & 0.0073 \\
\hline STD1 & $5.5-8.5$ & 0.5 & 5 & 0.02 & 1 & 3 & 0.05 & 0.01 & 0.005 & 0.001 & 0.01 \\
\hline STD2 & & 0.5 & & & & & 0.05 & & & & \\
\hline STD3 & $6,5-8.5$ & 0.3 & 0.3 & 0.02 & 1 & 3 & 0.01 & 0.01 & 0.003 & 0.001 & 0.01 \\
\hline
\end{tabular}

Note: STD1: Vietnam National Technical Regulations on ground water (QCVN09-MT 2015/BTNMT); STD2 Vietnam National Technical Regulations on domestic water (QCVN02:2009/BYT); SDT3: Vietnam National Technical Regulations on drinking water (QCVN01:2009/BYT)

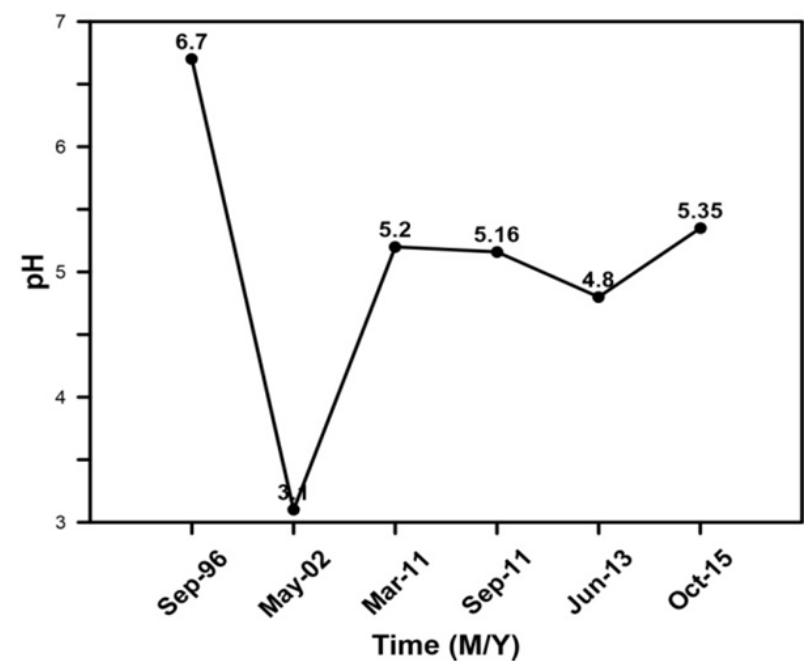

Figure 4. Variation of $\mathrm{pH}$ in Lake N.2 (old pit N.2) with time 
Vietnam Journal of Earth Sciences, 39(3), 210-224

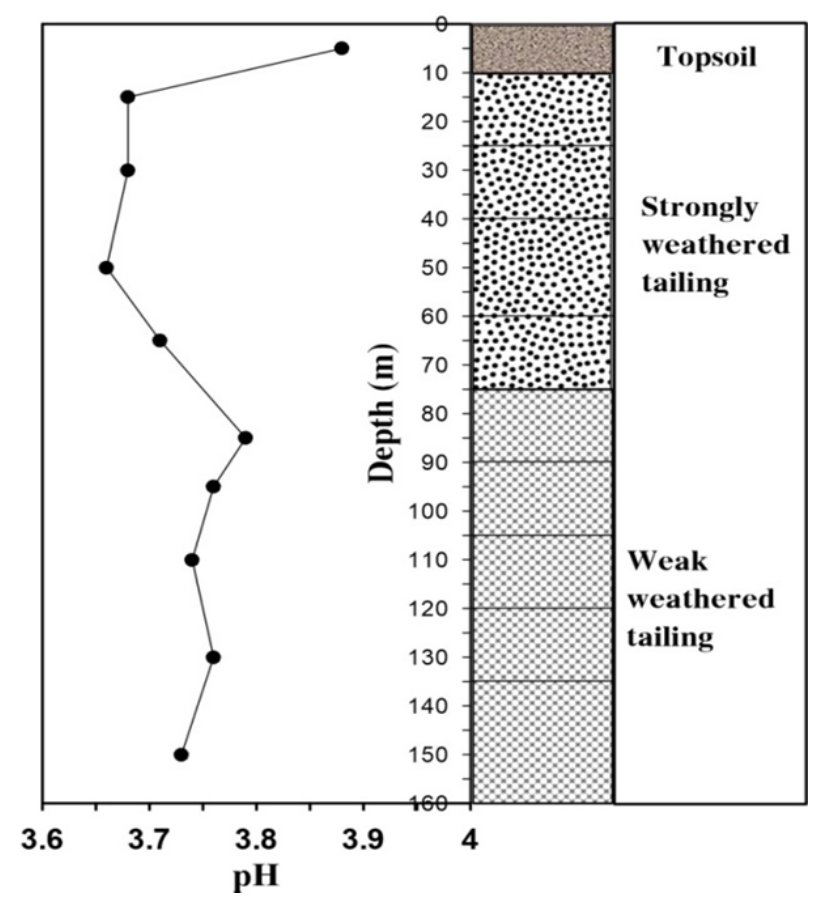

Figure 5. Variation of $\mathrm{pH}$ of waste material with depth in tailing N.1

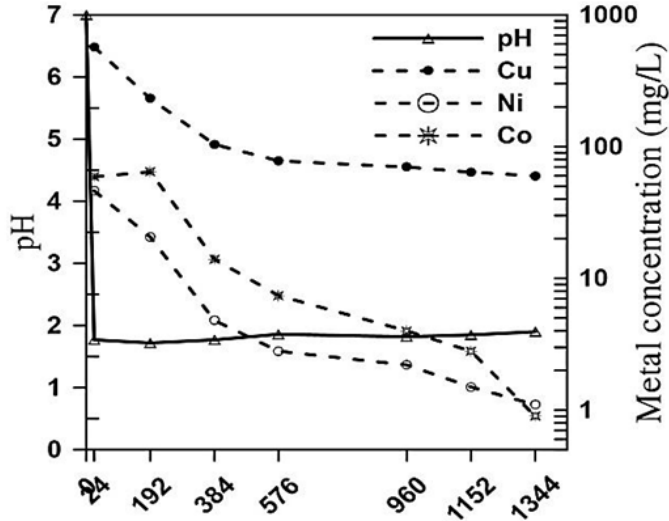

Time (h)

Figure 6. Variations of $\mathrm{pH}$ and concentrations of some metals with time in leaching experiments

Heavy metal concentrations of soil are shown in Table 7. Fe and Mn have relatively high contents raging from $40936.3 \mathrm{mg} / \mathrm{kg}$ (dry weight) to $157147.6 \mathrm{mg} / \mathrm{kg}$ and $41.23 \mathrm{mg} / \mathrm{kg}$ to $3309.29 \mathrm{mg} / \mathrm{kg}$ respectively. Concentrations of As vary from $6.34 \mathrm{mg} / \mathrm{kg}$ to 370.63 $\mathrm{mg} / \mathrm{kg}$ and 11 out of 20 analysed samples have As contents exceeded standard for agricultural soil (QCVN03-MT:2015/BTNMT). Concentrations of $\mathrm{Zn}$ range from $56.89 \mathrm{mg} / \mathrm{kg}$ to $420.61 \mathrm{mg} / \mathrm{kg}$ and 4 out of 20 collected samples have $\mathrm{Zn}$ contents exceeded standard. Other metals such as $\mathrm{Ni}, \mathrm{Cd}, \mathrm{Hg}, \mathrm{Pb}$ have low concentrations (Table 7), except for two samples $\mathrm{D} 11$ and $\mathrm{D} 14$ have high $\mathrm{Pb}$ contents $(146.92 \mathrm{mg} / \mathrm{kg}$ and $142.64 \mathrm{mg} / \mathrm{kg}$ respectively), doubly exceeding the standard values.

\section{Disscusion}

\subsection{Acid rock drainage}

Although Giap Lai pyrite mine has been closed for more than 10 years, the formation of acid rock drainage can be still observed in old pits and at many other places. Thus, 16 years after the mine closure acid drainage continues to occur in the old pits with low $\mathrm{pH}$ (Table 2 and Figure 4). Leakage appearing at the foot of the waste dumps and the tailing ponds is usually red in color and has very low $\mathrm{pH}$, especially in the rainy season (e.g., sam- 
Pham Tich Xuan, et al./Vietnam Journal of Earth Sciences 39 (2017)

ple $\mathrm{M} 6$ with $\mathrm{pH}$ at 3.63, Table 5). In the nearby rice paddies, where the acid leakage flows into, the rice withers in large strips (Figure 7).

As mentioned above, acid mine drainage or acid rock drainage formed by oxidation of sulfides, especially pyrite, which is the main mineral of the ore of Giap Lai mine, appears as the main cause of heavy metal pollution. High abundances of pyrite are still found in the old pits, waste dumps, tailings and former ore yards many years after the mine closure. The high concentration of pyrite under hot and high humidity tropical climate are viewed as ideal conditions for the acid rock drainage and heavy metal accumulation to form and disperse to the environment. As mentioned above, the sulfide minerals, especially pyrite, at surface condition can be easily oxidized to form sulfuric acid $\left(\mathrm{H}_{2} \mathrm{SO}_{4}\right)$. A summary equa- tion for this process is as follows (after Nordstrom et all, 1999):

$\mathrm{FeS}_{2}+15 / 4 \mathrm{O}_{2}+7 / 2 \mathrm{H}_{2} \mathrm{O}=\mathrm{Fe}(\mathrm{OH})_{3}+4 \mathrm{H}+$ $2 \mathrm{SO}_{4}^{2-}$

Surface water receives acid drainage and is directly affected, therefore many samples of surface water have lower $\mathrm{pH}$ values than a national standard (e.g., QCVN08MT:2015/BTNMT, B1: irrigation water). The $\mathrm{pH}$ values of water in Dong Dao stream from watershed after Lake No.2 to the confluent with the Bua River vary from 4.14 to 7.42 . In the upstream part where stream water directly receives acid drainage, the $\mathrm{pH}$ values are mostly low, but toward the downstream, the $\mathrm{pH}$ is rising because the stream water is diluted by other water sources unaffected by the ARD (Figure 8).

\begin{tabular}{|c|c|c|c|c|c|c|c|c|c|}
\hline Sampes & $\mathrm{Mn}$ & $\mathrm{Fe}$ & $\mathrm{Ni}$ & $\mathrm{Cu}$ & $\mathrm{Zn}$ & As & $\mathrm{Cd}$ & $\mathrm{Hg}$ & $\mathrm{Pb}$ \\
\hline D01 & 3046.17 & 141226.1 & 59.68 & 62.23 & 327.56 & 370.59 & 0.51 & 0.33 & 33.24 \\
\hline D02 & 247.32 & 130236.4 & 54.61 & 59.72 & 321.41 & 362.48 & 0.48 & 0.3 & 28.76 \\
\hline D03 & 47.82 & 157147.6 & 47.4 & 45.03 & 69.72 & 58.61 & 0.28 & 0.38 & 4.51 \\
\hline D04 & 41.23 & 139672.3 & 37.45 & 40.09 & 60.21 & 50.36 & 0.3 & 0.28 & 4.2 \\
\hline D05 & 43.15 & 147357.2 & 43.02 & 41.42 & 63.46 & 38.73 & 0.21 & 0.3 & 4.35 \\
\hline D06 & 45.64 & 134341.7 & 42.13 & 39.46 & 58.74 & 16.16 & 0.2 & 0.3 & 4.2 \\
\hline D07 & 42.17 & 128530.8 & 39.07 & 37.52 & 58.61 & 7.44 & 0.2 & 0.31 & 3.94 \\
\hline D08 & 51.43 & 78432.56 & 37.61 & 36.58 & 57.43 & 6.63 & 0.21 & 0.37 & 4.02 \\
\hline D09 & 49.89 & 68456.32 & 34.61 & 36.58 & 57.43 & 6.63 & 0.21 & 0.37 & 4.02 \\
\hline D10 & 47.76 & 65024.72 & 35.47 & 36.35 & 56.89 & 6.34 & 0.2 & 0.36 & 4.1 \\
\hline D11 & 3309.29 & 123610.9 & 94.67 & 86.16 & 420.61 & 104.57 & 0.75 & 0.37 & 146.92 \\
\hline D12 & 344.11 & 141126.5 & 59.71 & 62.24 & 327.68 & 370.63 & 0.5 & 0.33 & 33.22 \\
\hline D13 & 47.82 & 157147.6 & 47.4 & 45.03 & 69.72 & 58.61 & 0.28 & 0.38 & 4.51 \\
\hline D14 & 329.76 & 40936.3 & 48.47 & 65.65 & 68.06 & 6.34 & 0.23 & 0.34 & 142.64 \\
\hline D15 & 42.38 & 146461.4 & 32.54 & 43.27 & 59.67 & 37.35 & 0.21 & 0.32 & 4.41 \\
\hline D16 & 46.47 & 154326.1 & 45.13 & 41.3 & 62.43 & 25.42 & 0.25 & 0.34 & 4.05 \\
\hline D17 & 43.05 & 149425.7 & 42.01 & 40.58 & 64.52 & 11.03 & 0.24 & 0.33 & 4.36 \\
\hline D18 & 52.34 & 78432.6 & 36.24 & 37.52 & 58.61 & 7.44 & 0.2 & 0.36 & 3.94 \\
\hline D19 & 51.43 & 65024.7 & 34.61 & 36.58 & 57.43 & 6.63 & 0.21 & 0.37 & 4.02 \\
\hline D20 & 49.36 & 68463.2 & 35.47 & 36.35 & 56.89 & 6.34 & 0.2 & 0.36 & 4.1 \\
\hline STD & & & & 100 & 200 & 15 & 1.5 & & 70 \\
\hline
\end{tabular}

Note: D1 - D10: collected in rainy season; D11 - D20: collected in dry season; STD: Vietnam National Technical Regulations on agriculture soil (QCVN03-MT 2015/BTNMT)

Generally, at all the observed points, surface water in the rainy season usually has lower $\mathrm{pH}$ than in the dry season. This difference is explained by the mobility of acid formed by pyrite oxidation. In fact, the for- mation of acid is still ongoing even during the dry season, which is proven by the paste-pH experiments described above. However, in the dry season, the generated acid mostly remains in the pore water, whereas in the rainy season 
it is mobilized by precipitation to the surface flow, as a result, lowering the $\mathrm{pH}$ of surface water. This phenomenon has also been noted in many places (Pham Tich Xuan et al., 2011).

Notably, the samples contaminated with heavy metal with relatively low $\mathrm{pH}$ are found near waste dumps, tailing ponds or former mining pits. Acid generation and metal leaching potential of waste materials of Giap Lai mine have been proven by the experiments described above (Table 2 and 3). The negative correlation between $\mathrm{pH}$ values and heavy metal concentrations in surface water is shown using the Ficklin diagram (Figure 9).

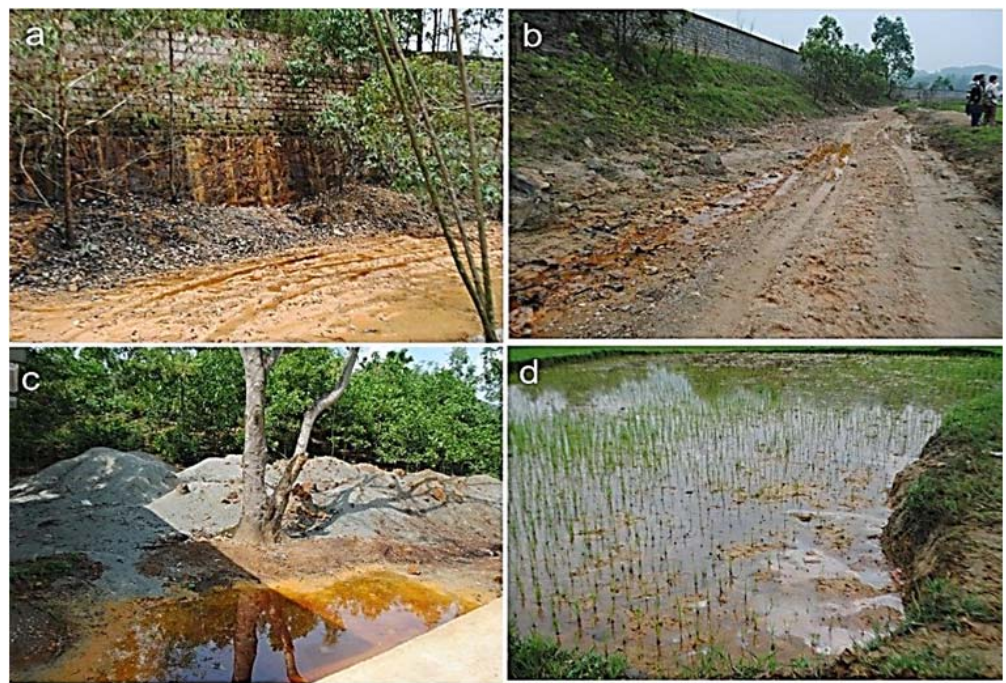

Figure 7. a, b: leakage from tailings and c: from former ore yards, d: the rice withers in large strips because of ARD. Low $\mathrm{pH}$ leakage is red in color

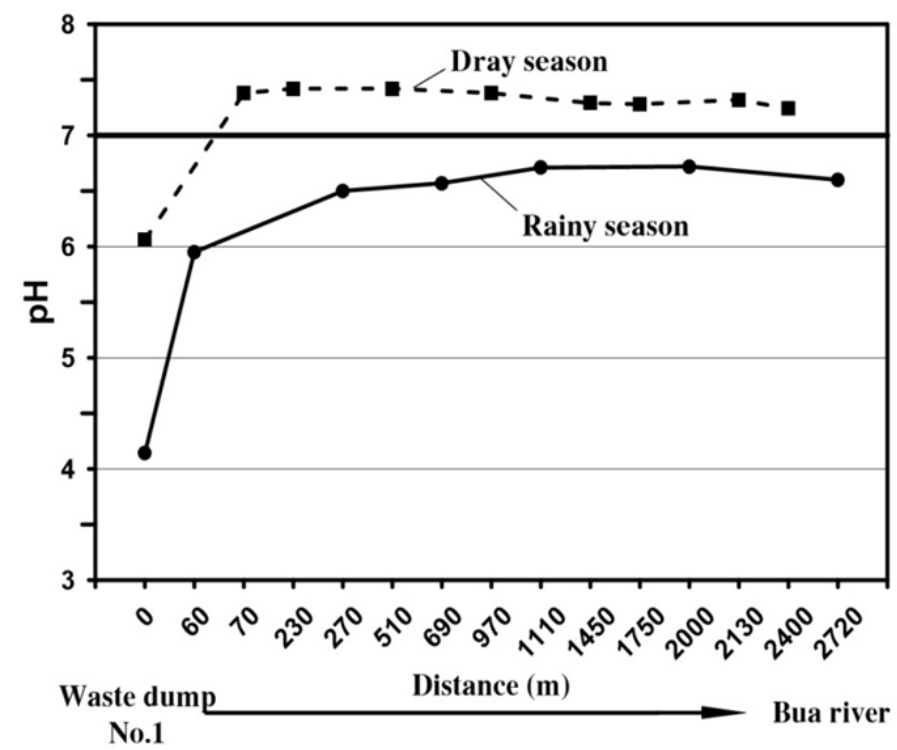

Figure 8. Graph showing the $\mathrm{pH}$ of Dong Dao stream from watershed to the Bua River 


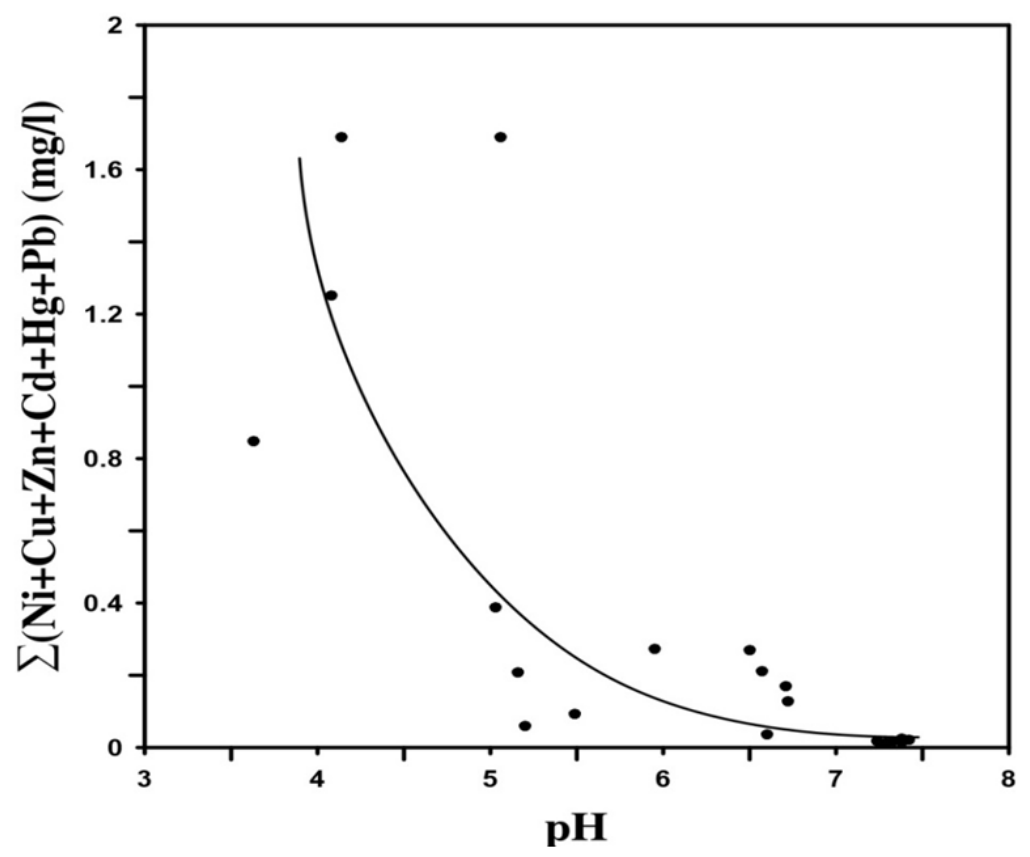

Figure 9. Ficklin diagram showing the correlation between $\mathrm{pH}$ and concentrations of heavy metals in surface water in Giap Lai mine area

\subsection{Assessment of heavy metal pollution}

\subsubsection{Surface water}

Except for $\mathrm{Fe}$ and $\mathrm{Mn}$, which usually are very high in content, concentrations of other heavy metals in the majority of surface water samples at Giap Lai are relatively low, ranging from the acceptable levels (after
QCVN08:2015/BTNMT, indicators B1), but the serious impact of acid drainage on the surface water can be seen when compared with the acid-free water from Bua River. Concentrations of metals in surface water at Giap Lai mining area much higher than in Bua River water (Figure 10).

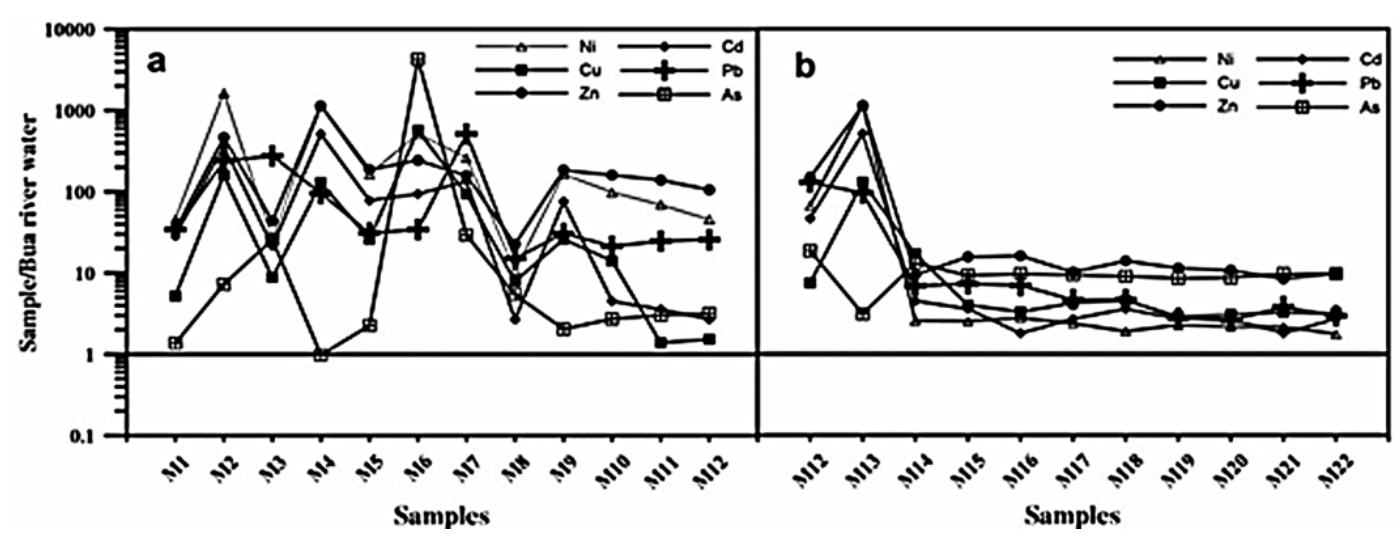

Figure 10. Concentrations of some metals in surface water in Giap Lai mine area normalized to those of Bua River water: a - rainy season, b- dry season 


\subsubsection{Ground water}

The most of the samples of well water in Giap Lai mining area have relatively low metal concentrations ranging from the standard for groundwater. However, well waters in the Giap Lai mining area are directly used for drinking without treatment. Thus, compared to technical regulation on domestic water (QCVN02:2009/BYT), 11 out of 15 collected samples are not met the $\mathrm{pH}$ standard values. Moreover, comparing to drinking water standards (QCVN01:2009/BYT), the figure is much worse. Also, some samples show concentrations of $\mathrm{Mn}, \mathrm{Fe}$, and $\mathrm{Ni}$ exceeding the drinking water standards. In conclusion, quality of the groundwater and the water supply in the Giap Lai mine and surrounding area are problematic, needed to be taken care of.

\subsubsection{Soil}

Soil samples show pollution with $\mathrm{As}, \mathrm{Cu}$ and $\mathrm{Zn}$, especially heavy in the rainy season, when 11 out of 20 collected samples are polluted with As. Other metals such as $\mathrm{Ni}, \mathrm{Cd}$, $\mathrm{Hg}$ have low concentrations (Table 6). Notably, two samples D11 and D14 have high Pb contents, double exceeding the standard values. Most of the polluted soil samples are dis- tributed near the old mining area and waste dumps.

\section{Geo-accumulation index}

The $I_{\text {geo }}$ of soil samples from Giap Lai mine area are shown in Table 8 . Ni has $I_{\text {geo }}$ ranging from -0.26 to 1.28 , classified as uncontaminated to moderately contaminated, while the average of $I_{\text {geo }}=0.22$ suggests the soil samples are uncontaminated to moderately contaminated. The $\mathrm{I}_{\mathrm{geo}}$ of $\mathrm{Cu}$ ranges from 1.14 to 2.38 suggesting that the soil is moderate to strongly contaminated and the average of $\mathrm{I}_{\text {geo }}=1.49$ indicates that the soil is moderately contaminated by this metal. Some samples have high $\mathrm{I}_{\text {geo }}$ values for As (up to 4.2), but the average $\mathrm{I}_{\text {geo }}$ for $\mathrm{As}=1.96$, indicating that the soil is moderately polluted by As. $\mathrm{Hg}$ has relatively high $\mathrm{I}_{\mathrm{geo}}$ and the average of geoaccumulation index of $\mathrm{Hg}\left(\mathrm{I}_{\text {geo }}=2.5\right)$ suggests that the soil is moderate to strongly contaminated by this metal. The $\mathrm{I}_{\mathrm{geo}}$ of $\mathrm{Zn}, \mathrm{Cd}$, and $\mathrm{Pb}$ are low and the all of the averages of geoaccumulation index of these metals are negative suggesting that the soil is uncontaminated by these metals. The $I_{\text {geo }}$ of soil samples from Giap Lai mining area show that soil in the study area is contaminated with $\mathrm{Ni}, \mathrm{Cu}$, As and $\mathrm{Hg}$.

Table 8. Geoaccumulation indexes $\left(I_{g e o}\right)$ of some metals in soil from Giap Lai mining ares $(n=20)$

\begin{tabular}{|c|c|c|c|c|c|c|c|}
\hline \multirow[b]{2}{*}{ Metal } & \multicolumn{4}{|c|}{ Concentration (mg/kg) } & \multirow[b]{2}{*}{$\mathrm{B}_{\mathrm{n}}($ IAEA-7) } & \multirow[b]{2}{*}{ Range of $\mathrm{I}_{\mathrm{geo}}$} & \multirow[b]{2}{*}{$\mathrm{I}_{\text {geo }}$ (Aveg.) } \\
\hline & $\bar{X}$ & Min & Max & $\mathrm{SD}$ & & & \\
\hline $\mathrm{Ni}$ & 45.37 & 32.54 & 94.67 & 14.16 & 26.0 & $-0.26 \div 1.28$ & 0.22 \\
\hline $\mathrm{Cu}$ & 46.48 & 36.35 & 86.16 & 13.51 & 11.0 & $1.14 \div 2.38$ & 1.49 \\
\hline $\mathrm{Zn}$ & 118.85 & 56.89 & 420.61 & 119.80 & 104.0 & $-1.46 \div 1.43$ & -0.39 \\
\hline As & 77.92 & 6.34 & 370.63 & 127.59 & 13.4 & $-1.66 \div 4.20$ & 1.96 \\
\hline $\mathrm{Cd}$ & 0.29 & 0.20 & 0.75 & 0.15 & 1.3 & $-3.29 \div-1.38$ & -2.73 \\
\hline $\mathrm{Hg}$ & 0.34 & 0.28 & 0.38 & 0.03 & 0.04 & $2.22 \div 2.66$ & 2.50 \\
\hline $\mathrm{Pb}$ & 22.38 & 3.94 & 146.92 & 43.05 & 60.0 & $-4.51 \div 0.71$ & -2.01 \\
\hline
\end{tabular}

\section{Conclusions}

Although Giap Lai pyrite mine has been closed down for many years the ARD still occurs and negatively impacts on quality of water and soil in the mining area.
Surface water in the mining area usually has relatively low $\mathrm{pH}(<5.5)$ and does not meet the Standard for irrigation water (QCVN08-MT:2015/BTNMT). The levels of $\mathrm{Fe}$ and $\mathrm{Mn}$ in surface water are very high, especially in the rainy season, in wich some 
Pham Tich Xuan, et al./Vietnam Journal of Earth Sciences 39 (2017)

samples have Fe content up to 300 times, or/and Mn content up to 30 times higher than the Standards on irrigation water. Surface water shows slightly pollution of $\mathrm{Ni}$ and $\mathrm{As}$, while other heavy metals such as $\mathrm{Cu}, \mathrm{Zn}, \mathrm{Cd}$, $\mathrm{Pb}, \mathrm{Hg}$ are lower than allowed limits. However, metal levels of surface water in mining area are much higher compared to the Bua River water, indicating metal contamination of surface water.

Generally, well water in Giap Lai mining area has $\mathrm{pH}$ and metal concentrations within the limit for groundwater (QCVN09MT:2015/BTNMT). However, compared with standards for drinking and domestic water (QCVN01:2009/BYT and QCVN02:2009/BYT), the most of the well water have $\mathrm{pH}$ below the limit. Some samples show concentrations of $\mathrm{Mn}, \mathrm{Fe}$, and $\mathrm{Ni}$ exceeding the drinking water standards

Soil in mining area is polluted with $\mathrm{Cu}, \mathrm{Zn}$, $\mathrm{Pb}$, especially in the rainy season. The geoaccumulation indexes show that soil in the study area is contaminated with $\mathrm{Ni}, \mathrm{Cu}$, As and $\mathrm{Hg}$.

Pyrite-rich tailings and waste rocks are sources of ARD, causing elevated metal levels in downstream water bodies and soils, so samples located closely to these sources usually show contamination with metals.

Regardless of the fact that the mine is at an uncontrolled state after its closure with no post-closure remediation measures having been applied. The ARD originated from waste dumps and tailing ponds leaks out and flows into the nearby surface water bodies. Therefore, the risk of ARD and heavy metal contamination in this area remains high and will continue to affect the environmental quality. The research provides a series of evidence to suggest that the Environmental Protection Law should be fully implemented not only during mining but also after its closure.

\section{Acknowledgements}

This research work was financed by VAST Project (VAST05.05/15-16).

\section{References}

AMIRA, 2002. ARD Test Handbook. Project P387A Prediction \& Kinetic Control of Acid Mine Drainage. AMIRA international May 2002, 42p.

Çevik F., Göksu M.Z.L., Derici O.B., Fındık Ö., 2009. An assessment of metal pollution in surface sediments of Seyhan dam by using enrichment factor, geoaccumulation index and statistical analyses. Environmental Monitoring and Assessment 152, 309-317.

EPA, 2000. Abandoned mine site characterization and cleanup hand book, 129p, (https://yosemite.epa.gov/r10/amscch.pdf).

Ghrefat H.A., Abu-Rukah Y., Rosen M.A., 2011. Application of geoaccumulation index and enrichment factor for assessing metal contamination in the sediments of Kafrain Dam, Jordan. Environmental Monitoring and Assessment 178, 95-109.

IAEA, 2000. Reference Sheet, reference material. Trace elements in soil. (https://nucleus.iaea.org/rpst/Documents/rs_iaeasoil-7.pdf).

INAP, 2009. Global Acid Rock Drainage Guide. International Network for Acid Prevention. (http://www.gardguide.com/index.php/Main_Page).

Loska K., Wiechula D., Korus I., 2004. Metal contamination of farming soils affected by industry. Environment International Vol.30 (Iss.2), 159-165.

MCMPR/MCA, 2010. Strategic Framework for Managing Abandoned Mines in the Minerals Industry, http://www.industry.gov.au/resource/Mining/Docum ents/StrategicFrameworkforManagingAbandonedMi nes.pdf.

Mhlongo S.E. and Amponsah-Dacosta F., 2015. A review of problems and solutions of abandoned mines in South Africa, International Journal of Mining, Reclamation and Environment, DOI: 10.1080/17480930.2015.1044046.

Müller G., 1969. Index of geoaccumulation in sediments of the Rhine River. Geojournal 2, 108-118.

Newton G. et al., 2000. California's Abandoned Mines. A Report on the Magnitude and Scope of the Issue in the State, Vol.1, 60p.

Http://www.conservation.ca.gov/omr/abandoned_mine_1 ands/AML_Report/Documents/volume1 textonly.pdf 
Vietnam Journal of Earth Sciences, 39(3), 210-224

Nordstrom D.K., Alpers C.N., 1999. Geochemistry of acid mine waste. In "Review in Economic Geology, the environmental geochemistry of ore deposits"/Eds. G.S. Plumlee, M.J. Logsdon. Part A: Processes, techniques, and health issues Vol.6A, 133-160.

Nowrouzi M. and Pourkhabbaz A., 2014. Application of geoaccumulation index and enrichment factor for assessing metal contamination in the sediments of Hara Biosphere Reserve, Iran. Chemical Speciation and Bioavailability, 26(2),99-105.

Pham Tich Xuan, Nguyen Van Pho, Hoang Tuyet Nga, Doan Thi Thu Tra, Cai Van Truong, Nguyen Van Thu, Vu Manh Long, 2010. Heavy metal pollution in some metal mines in the Northern Vietnam. Procceding of Conference in commemoration of the 35th day of Establish of VAST. Environment and Energy, Hanoi, 236-244 (in Vietnamese with English abstract).

Sobek A.A., Schuller W.A., Freeman J.R. and Smith R.M., 1978. Field and laboratory methods applicable to overburden and minesoils. Report EPA 600/2-78054, US Environmental Protection Agency, 204p.
Tarras-Wahlberg N.H, Lan T. Nguyen, 2008. Environmental regulatory failure and metal contamination at the Giap Lai pyrite mine. Northern Vietnam. Journal of Environmental Management, 86(4), 712-720.

Tran Xuan Toan, 1963. Some characteristics of pyrite mineralization in the Giap Lai deposit, Phu Thọ. Geology 10, 18-24, Hanoi (in Vietnamese).

Wei Z., Wang D., Zhou H., Qi Z., 2011. Assessment of Soil Heavy Metal Pollution with Principal Component Analysis and Geoaccumulation Index. Procedia Environmental Sciences, 10, 1946 -1952.

Zawadzki J. and P. Fabijan'czyk P., 2013. Geostatistical evaluation of lead and zinc concentration in soils of an old mining area with complex land management. Int. J. Environ. Sci. Technol. 10, 729-742.

Ziemkiewicz P., Renton J. and Rymer T., 1991. Prediction and Control of Acid Mine Drainage: Effect of Rock Type and Amendment. Proceedings Twelfth Annual West Virginia Surface Mine Drainage Task Force Symposium, April 3-4, Morgantown, West Virginia, Vol.1, 51-54. 